\title{
The Quality of Natural Pozzolanic Materials at Bayoda desert in Northern Sudan
}

\author{
Eltayeb A/Ellatif Ahmed Habib ${ }^{1}$, Salih Elhadi. M. Ahmed ${ }^{2}$ \\ 1. Doctoral Candidate (Sudan Academy of Sciences), Lecturer, Faculty of Engineering and architect, \\ University of Bahari, Sudan, \\ 2. Professor of structural engineering -Sudan University for Science and Technology, Sudan,
}

\begin{abstract}
The importance of Cement as a binding material is increased with the onset of the development and the physical renaissance. Due to the highly demand of OPC (for concrete and other purpose of construction) it becames expensive and scarce commodity and this has severely limited the construction of affordable housing in Sudan. This large demand needs another alternative material from two points of view, economically and availability. The objective of this study is to find other alternative binding materials that can be blended with OPC to enhance the properties of fresh and hardened concrete as well as to reduce the economical phase of cement. Three Pozzolanic samples ,represent natural Pozzolana, were brought from different location at Bayoda desert.

The samples were grounded firstly and tested for the chemical contents and after that mixed with partial replaced in the ratio of $0 \%, 10 \%, 20 \%$, and $30 \%$ by weight of OPC to form concrete to detect the fresh and hardened properties of the mix.

The results recorded were showed that all the three samples are reactive material with amorphous silica and alumina that fulfilled the requirement of the Pozzolanic properties.

The better strength tests were reached with sample S2 with OPC, which gave range of developing of compressive strength between 0.83 up to $0.96 \%$ in comparison with pure OPC. And gave some enhancement in workability of the mixes comparing to pure OPC mix.

The recommendation is that The Quality of Natural Pozzolanic material at Bayoda desert is good and confirm with the standard properties of natural Pozzolana. And can be mixed with OPC in the above proportions to be used as Pozzolanic Cement to enhance some properties of concrete and mortars.
\end{abstract}

Keywords: Pozzolanic materials, Blended Cement, Chemical Composition, Workability, Compressive Strength.

\section{INTRODUCTION}

From 1880 - 1996, the world's annual consumption of Portland cement rose from 2 million tons to 1.3 billion ton. This was associated with major environmental cost include: a) cement manufacturing is the third largest $\mathrm{CO}_{2}$ producer and for over $50 \%$ of all industrial $\mathrm{CO}_{2}$ emissions (for every 1 ton of cement produced, 1.25 tons of $\mathrm{CO}_{2}$ is released in the air); b) 1.6 tons natural recourse is consumed to produce 1 ton of cement. This calls for the use of other alternative sustainable binders. One of the most promising materials is Pozzolanic materials ${ }^{(10)}$.

The importance of Cement as a binding material is increased with the onset of the development and the physical renaissance. Now concrete is an important material for building construction, the present annual world production of concrete is above billion cubic meters. Due to this highly demand of OPC (for concrete and other purpose of construction) it became expensive and scarce commodity and this has severely limited the construction of affordable housing in much of the third world. This large demand needs another alternative material from two points of view, economically and availability ${ }^{(1)}$.

Alternative cements provide an excellent technical option to OPC at much lower cost.

Pozzolanas are an important ingredient in the production of alternative cementing materials to Portland cement. Pozzolanic materials are materials that containing reactive silica andlor alumina, which in their own have little or no binding properties but when mixed with lime in the presence of water it will set and harden like cement ${ }^{(2)}$. Pozzolanic materials are not a new materials, it is known to have been used by the Egyptians some 2,000 years BC. The use of lime - based mortar for the floors of huts has also been found in excavations dated long ago as 5600BC.

\section{BACKGROUND}

The raw materials of the natural Pozzolanic materials are available and distributed over a wide area of the Sudan regions. There are many locations for natural pozzolanas in Sudan. 
Bayoda Desert is one of these locations. Bayoda Desert lies west Atbara town in northern state and it is characterized by the presence of Pozzolanic materials in the form of ash in northern volcanic field, and as burnt clay underlying the basaltic lava flow in the southern part (J.Um Arafaiba).

The main volcanic field extends over a length of $50 \mathrm{~km}$ and width of $20 \mathrm{~km}$ occupies an area of almost $1000 \mathrm{~km}^{2}$. (3)

Three samples were brought from different lacation at Bayoda desert represent the following types:

1. Natural burnt clay from southern part of the Bayoda desert in Mindraba area.(at coordinates N 17 $30.3^{\prime}$, E $33^{\circ} 13.3^{\prime}$ which was formed by basaltic flow overlying the clay bed which resulted in the heating and burning the underlying clay layer completely.(Sample S1).

2. Volcanic Ash extending in a northwesterly direction from N $188^{\circ} 17^{\prime}-\mathrm{E} 32^{\circ} 55^{\circ}$ to N $18^{\circ} 20^{\prime}-\mathrm{E} 32^{\circ} 29^{\prime}$. (Sample S2).

3. Pumice in northern volcanic field of Bayoda associated with basaltic lava and contaminated in some occurrences with the basalt of Bayoda Volcanic field. (Sample S3).

\section{MATERIALS AND METHODS}

3.1 Cement and aggregate: Ordinary Portland cement (OPC) produced from Atbara Cement Company was used. And standard fine and coarse aggregate conforming to British Standards BS 882 grading zone M for coarse \& fine Aggregates were used for the preparation of concrete specimens.

Locally available free of debris sand is used as fine aggregate. The sand particles should also pack to give minimum void ratio, higher voids content leads to requirement of more mixing water. Those fractions from $4.75 \mathrm{~mm}$ to 150 micron are termed as fine aggregate or sand.

The size of coarse aggregate used was ranged between $14 \mathrm{~mm}$ as maximum and $2.36 \mathrm{~mm}$ as minimum, and are tested as BS 882 grading zone M for coarse Aggregates and the results are within the permissible limit.

3.2 Bayoda Pozzolanic samples: For this study three samples were brought from Bayoda desert. (Natural burnt clay, Volcanic ash and Pumice). The samples were grounded and sieved to grain size of less than $63 \mu \mathrm{m}$.

Preparation of the Specimens: Concrete cubes of size 150x150x150mm, were prepared and cured using the three Pozzolanic samples from Bayoda desert blended OPC cement. The OPC was replaced with 10, 20, and $30 \%$ Pozzolanic materials under study Table (1).

\section{DESIGN METHOD}

The mix design adopted in this investigation followed a method suggested by Cabrera based on a mix of maximum packing of Cement and sand particles strength and minimum porosity which has a cement : sand: coarse aggregates ratio of 1:2.33:3.5 Table (1)

This is the mix used as a control in the laboratories of concrete materials. The compositions of the different mixes used in the Investigation are given in Table (1).

The samples were incorporated in the mixes at $30 \%, 20 \%$, and $10 \%$ replacement levels, the mixes (OPC/Si) were made with the same W/C ratio of 0.55 as the OPC mix to observe the effect of the Si materials on the workability and strength.

Where: Si represent the three samples that were brought from Bayoda desert. (Natural burnt clay, Volcanic Ash and Pumice).

Changes in Concrete properties investigated were then related to:

1. Varying the percentage of replacement of the OPC with others samples proportions of Pozzolana under study $(10 \%, 20 \%$, and $30 \%)$.

2. Different types of Pozzolanic samples under study.

Table (1) concrete mix proportions (by weight)

\begin{tabular}{|llllll|} 
Mix & OPC & Bayoda Pozzolanic samples $\left(\mathbf{S}_{\mathbf{i}}\right)$ & Sand & Gravel & water \\
\hline OPC & 1 & 0 & 2.33 & 3.5 & 0.55 \\
\hline OPC/ $\mathbf{S}_{\mathbf{i}}$ & 0.9 & 0.1 & 2.33 & 3.5 & 0.55 \\
\hline $\mathbf{O P C}_{\mathbf{i}}$ & 0.8 & 0.2 & 2.33 & 3.5 & 0.55 \\
\hline $\mathbf{O P C}_{\mathbf{S}} \mathbf{S}_{\mathbf{i}}$ & 0.7 & 0.3 & 2.33 & 3.5 & 0.55 \\
\hline
\end{tabular}

Where $\mathrm{S}_{\mathrm{i}}$ represent $\mathrm{S} 2, \mathrm{~S} 3 \& \mathrm{~S} 4$

\section{MIXING AND CASTING}

The fresh concrete was mixed using flow pan mixer of $150 \mathrm{Kg}$ capacity till uniform through consistency was achieved, prior to the mixing; the materials were spread in layers in the bottom of the pan, coarse aggregate first, followed by cement and finally the fine aggregate. The constituents of the mixes were mixed dry for one minute in order to homogenize the batched mix; subsequently water was added and mixed for a further three minutes. The concrete was cast into the moulds in three layers, and 36 blows were given to each layer, using 
$16 \mathrm{~mm}$ diameter bar, to remove any entrapped air. For each mix the required numbers of cubes (total of 150 cubes) were casted. The moulds were covered by sacking for 24 hours at room temperature. The specimens were de-molded after at least 24 hours and immersed into the curing tank.

Before the molding of the samples specimens workability tests were done to observe the effect of the samples S1, S2, \& S3 on fresh concrete properties. The workability tests adopted for this investigation were the Slump test and compacting factor test. The results of the Slump and compacting factor tests for the various mixes were listed in Table (3) below.

Compressive strength was conducted at the age of $3,7,14,28$, and 90 days. The results were listed in Table (4).

\section{Chemical composition:}

\section{PRESENTATION OF RESULTS \& DISCUSSIONS}

Table (2) chemical properties of study samples in comparison with OPC

\begin{tabular}{|c|c|c|c|c|c|c|c|c|}
\hline \multirow[t]{2}{*}{ Material } & \multicolumn{8}{|c|}{ Chemical composition (\%) } \\
\hline & $\mathrm{SiO}_{2}$ & $\mathrm{Al}_{2} \mathrm{O}_{3}$ & $\mathrm{Fe}_{2} \mathrm{O}_{3}$ & $\mathrm{CaO}$ & $\mathrm{MgO}$ & $\mathrm{SO}_{3}$ & $\mathrm{~K}_{2} \mathrm{O}$ & LOI \\
\hline OPC & 21.26 & 5.1 & 2.59 & 64.96 & 2.02 & 1.8 & 0.3 & 2.0 \\
\hline S1 & 57.57 & 8.6 & 8.96 & 3.8 & 1.45 & 0.21 & 0.25 & 12.8 \\
\hline S2 & 54.95 & 9.26 & 8.67 & 8.14 & 9.31 & 0.49 & 1.13 & 11.9 \\
\hline S3 & 50.30 & 10.31 & 15.52 & 8.31 & 6.20 & 0.17 & 0.95 & 12.3 \\
\hline
\end{tabular}

As the one of the main factors that affects the activity of Pozzolana is the chemical composition, so according to the ASTM C618 \& TS 25 (min. $\mathrm{SiO}_{2}+\mathrm{Al}_{2} \mathrm{O}_{3}+\mathrm{Fe}_{2} \mathrm{O}_{3}$ ), all the three samples give good indication for good Pozzolanic activity.

\section{Workability:}

Table (3) Slump tests and compacting factor tests results

\begin{tabular}{|ccccc|}
\hline Sample No. & Pozzolana & Cement & Slump (mm) & Compacting factor \\
\hline OPC & 0 & 100 & $22 \pm 2$ & 1.05 \\
\hline S1 & 10 & 90 & $18 \pm 2$ & 1.10 \\
\cline { 2 - 5 } & 20 & 80 & $16 \pm 2$ & 1.11 \\
\cline { 2 - 5 } & 30 & 70 & $15 \pm 2$ & 1.12 \\
\hline \multirow{2}{*}{ S2 } & 10 & 90 & $20 \pm 2$ & 1.98 \\
& 20 & 70 & $24 \pm 2$ & 0.94 \\
\hline & 30 & 90 & $25 \pm 2$ & 1.12 \\
\hline & 10 & 80 & $19 \pm 2$ & 1.14 \\
\hline & 20 & 70 & $17 \pm 2$ & 1.15 \\
\hline
\end{tabular}

The workability tests results (Figure 1) indicated that addition of S1 reduced the workability. It could have been caused due to the adsorption of water at the surface of clay. The higher the proportion of S1, the higher was the adsorption of water and hence lower amount of water reduced the workability, further. Also the high percentage of LOI may affect the degree of water absorption and in turn affect the workability.

The addition of sample S2 (Figure 2) shows some enhance in workability and this may be putted under more study to be used as workability enhancement additives after determining the optimum percentage replacement. For sample S3 (Figure 3) there is very few reduction in workability values with increase in the replacement proportions may be due to high value of LOI.

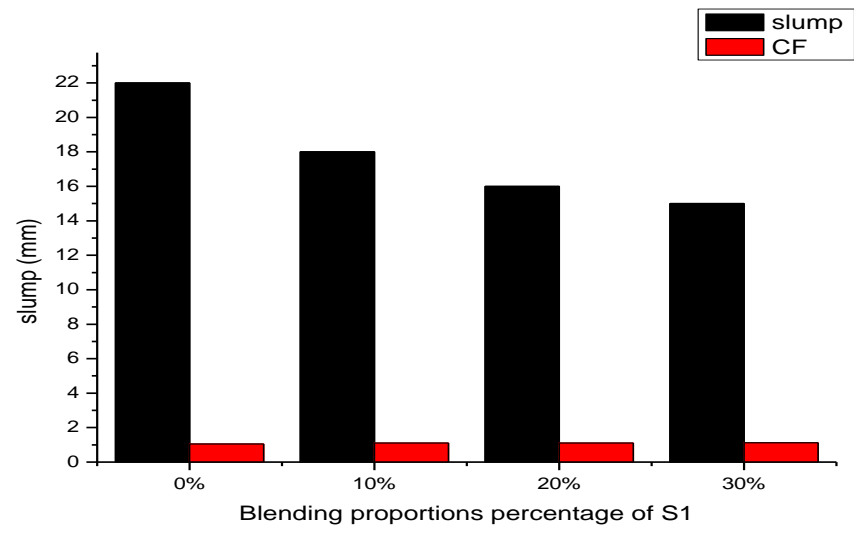

Figure (1) The effect of (S1) Cement replacement on workability 


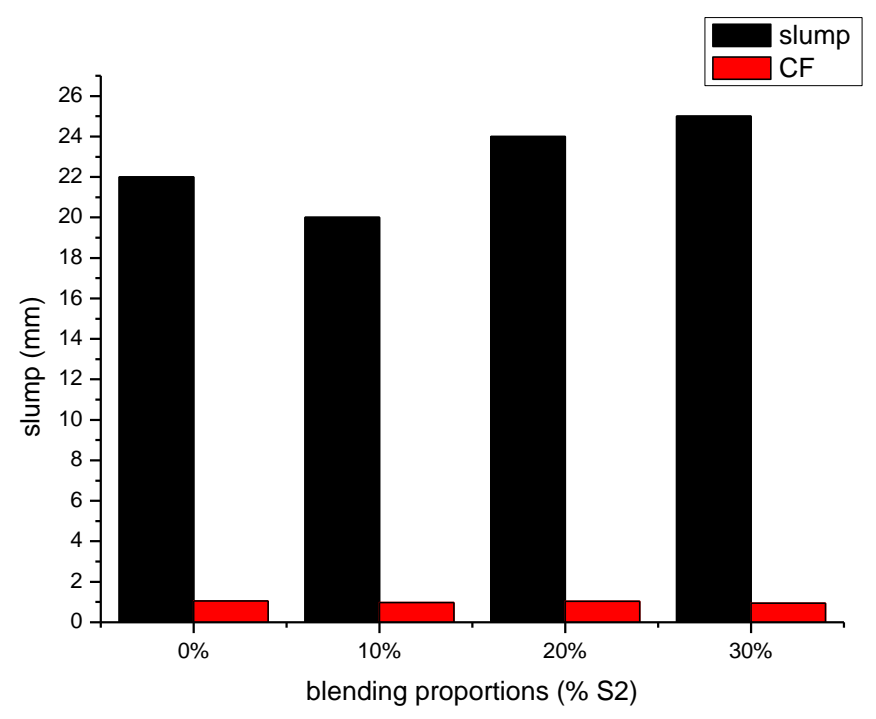

Figure (2) The effect of (S2) Cement replacement on workability

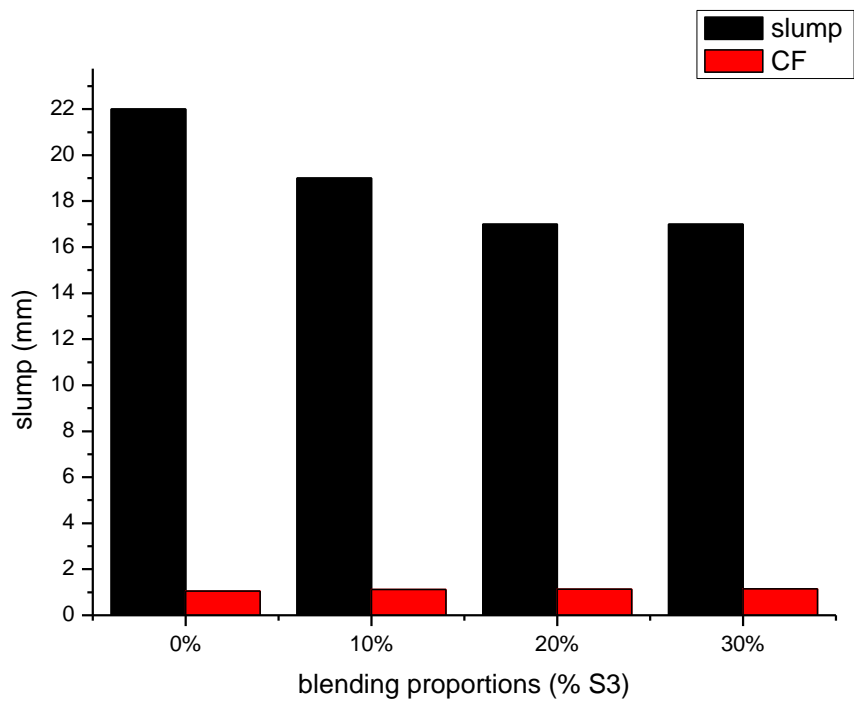

Figure (3) The effect of (S3) Cement replacement on workability

Compressive Strength Development:

Table (4): Strength activity development of blended concrete at 3, 7, 14, 28 and 90 days.

\begin{tabular}{|c|c|c|c|c|c|c|c|}
\hline \multirow[t]{2}{*}{ Sample No. } & \multicolumn{2}{|c|}{ Blending \% } & \multicolumn{5}{|c|}{ Compressive strength $\left(\mathrm{N} / \mathrm{mm}^{2}\right)$} \\
\hline & & & 3 days & 7 days & 14 days & 28 days & 90 days \\
\hline OPC & 0 & 100 & 22 & 28 & 32 & 35 & 35.5 \\
\hline \multirow[t]{3}{*}{ S1 } & 10 & 90 & 18 & 20 & 26 & 29.5 & 33 \\
\hline & 20 & 80 & 16 & 19 & 22 & 25 & 26.5 \\
\hline & 30 & 70 & 14 & 17 & 21 & 24 & 25 \\
\hline \multirow[t]{3}{*}{ S2 } & 10 & 90 & 21 & 27.5 & 29.5 & 32.5 & 34 \\
\hline & 20 & 80 & 19 & 23 & 27 & 29 & 31.5 \\
\hline & 30 & 70 & 15 & 18.5 & 22.5 & 26 & 29.5 \\
\hline \multirow[t]{3}{*}{ S3 } & 10 & 90 & 17 & 21 & 24 & 31 & 32 \\
\hline & 20 & 80 & 15 & 19 & 22.5 & 28 & 29 \\
\hline & 30 & 70 & 14 & 17.5 & 19.5 & 25.5 & 28.5 \\
\hline
\end{tabular}

Results of compressive strength test conducted on cubes specimens, represented graphically in Fig. (4, 5, \& 6), showed that during experiment age of testing, all blended cubes specimens exhibited lower strength than OPC at the early stages. This was due to the combined effect of relative fineness and the Pozzolanic activity of the Samples. But sample S2 shows relatively development in strength at $28 \& 90$ days. The samples (S1 \& S3) were 
shown some reduction in strength development than OPC. The compressive strength values decreases with increase in the substitution ratio of Pozzolanic samples used.

The reduction in strength development for sample S1 may be due to the existing of some crystalline silica. And also may be due to hydration reaction specimens with possible low reactivity of $\mathrm{SiO}_{2}$ and also the reduction in $\mathrm{CaO}$ contents may have caused the reduction in ultimate strength development.

According to Bui ${ }^{(9)}$ strengthening capability of a mineral admixture not only depends on the Pozzolanic reactivity, but also on the relative fineness of the filler material. At 90 day stage compressive strength for S2 was shown clear developing strength ranging between $83 \%$ up to $0.96 \%$ of OPC depending on the percentage replacement of OPC, this may be due to chemical action of the Pozzolanic reaction between calcium hydroxide $(\mathrm{CH})$ and silica $\left(\mathrm{SiO}_{2}\right)$. Also the hydration of silica itself in the alkaline environment may have been responsible for increase in compressive strength.

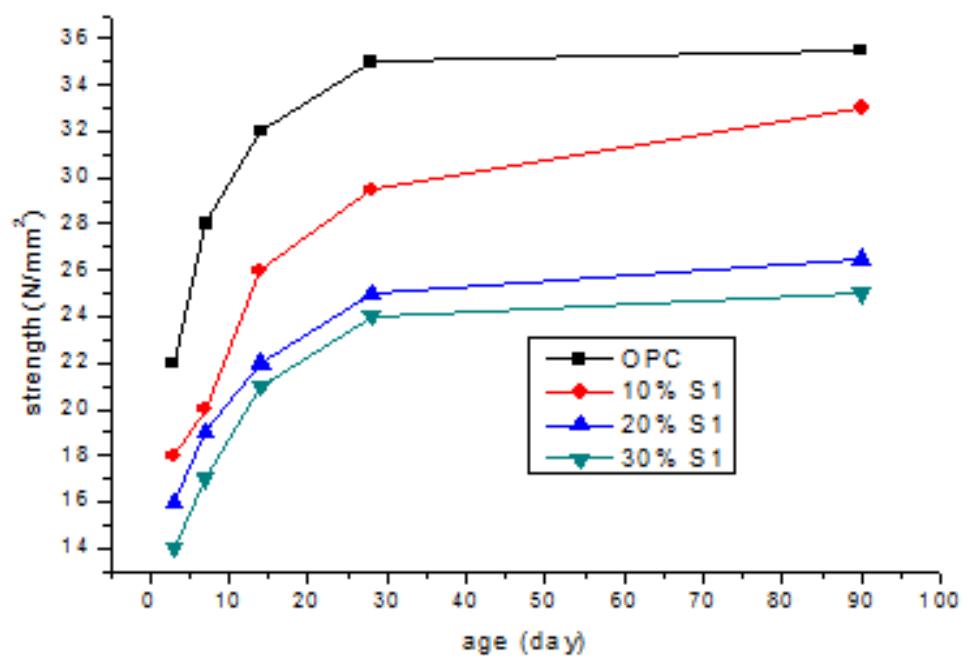

Figure (4) Strength development throughout the ages of S1 Sample replacement proportions compared with OPC.

$$
\begin{aligned}
& f^{\prime}=27.418+0.1085 \mathrm{~d} \ldots \ldots \ldots \ldots \ldots \ldots \ldots . .(1) . \text { For } \mathrm{OPC}\left(\mathrm{R}^{2}=0.303\right) \\
& f^{\prime}=21.06+0.149 \mathrm{~d} \ldots \ldots \ldots \ldots \ldots \ldots \ldots \ldots(2) . \text { For } 10 \% \mathrm{~S} 1\left(\mathrm{R}^{2}=0.620\right) \\
& f^{\prime}=18.96+0.097 \mathrm{~d} \ldots \ldots \ldots \ldots \ldots \ldots \ldots .(3) . \text { For } 20 \% \mathrm{~S} 1\left(\mathrm{R}^{2}=0.525\right) \\
& f^{\prime}=17.371+0.1 \mathrm{~d} \quad \ldots \ldots \ldots \ldots \ldots \ldots \ldots \ldots . .(4) . \text { For } 30 \% \mathrm{~S} 1\left(\mathrm{R}^{2}=0.445\right)
\end{aligned}
$$

Where: $f^{\prime}$ is the strength in $\mathrm{N} / \mathrm{mm}^{2}$ and $\mathrm{d}$ is the age in days

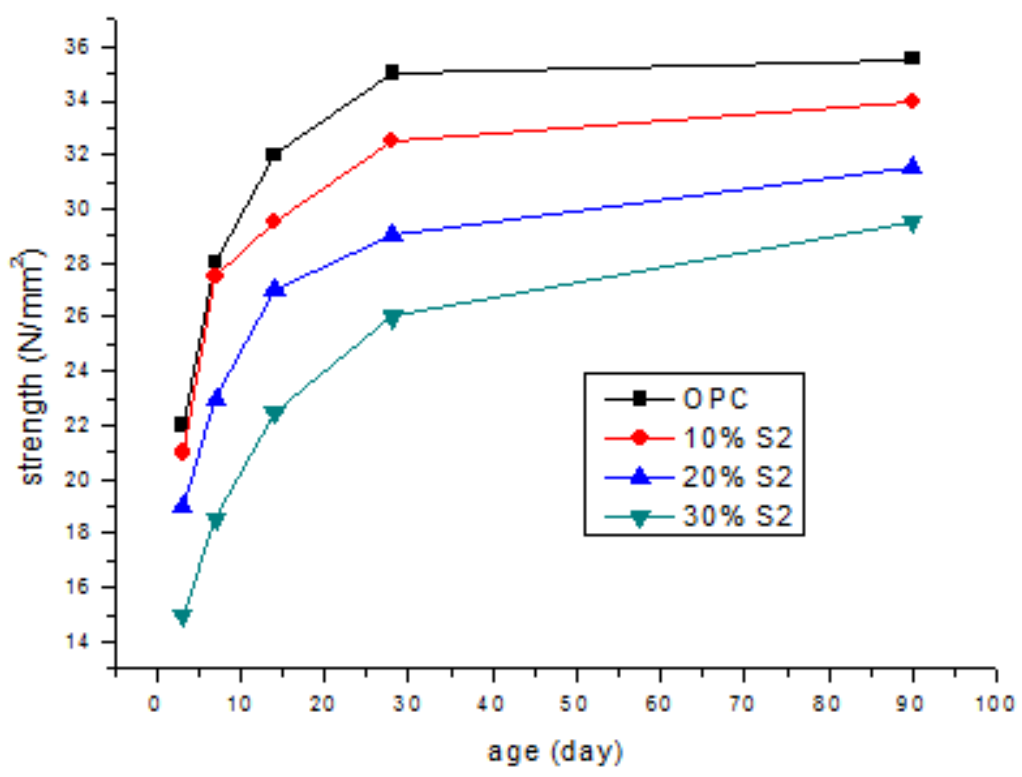

Figure (5) Strength development throughout the ages of S2 Sample replacement proportions compared with OPC. 


$$
\begin{aligned}
& f^{\prime}=27.418+0.1085 \mathrm{~d} \\
& \text { (1). For OPC }\left(\mathrm{R}^{2}=0.303\right) \\
& f^{\prime}=25.925+0.105 \mathrm{~d} \text {. } \\
& \text { (2). For } 10 \% \mathrm{~S} 2\left(\mathrm{R}^{2}=0.387\right) \\
& f^{\prime}=22.756+0.111 d \\
& f^{\prime}=18.373+0.138 \mathrm{~d} \\
& \text { (3). For } 20 \% \mathrm{~S} 2\left(\mathrm{R}^{2}=0.516\right) \\
& \text { (4). For } 30 \% \mathrm{~S} 2\left(\mathrm{R}^{2}=0.643\right)
\end{aligned}
$$

Where: $f^{\prime}$ is the strength in $\mathrm{N} / \mathrm{mm}^{2}$ and $\mathrm{d}$ is the age in days

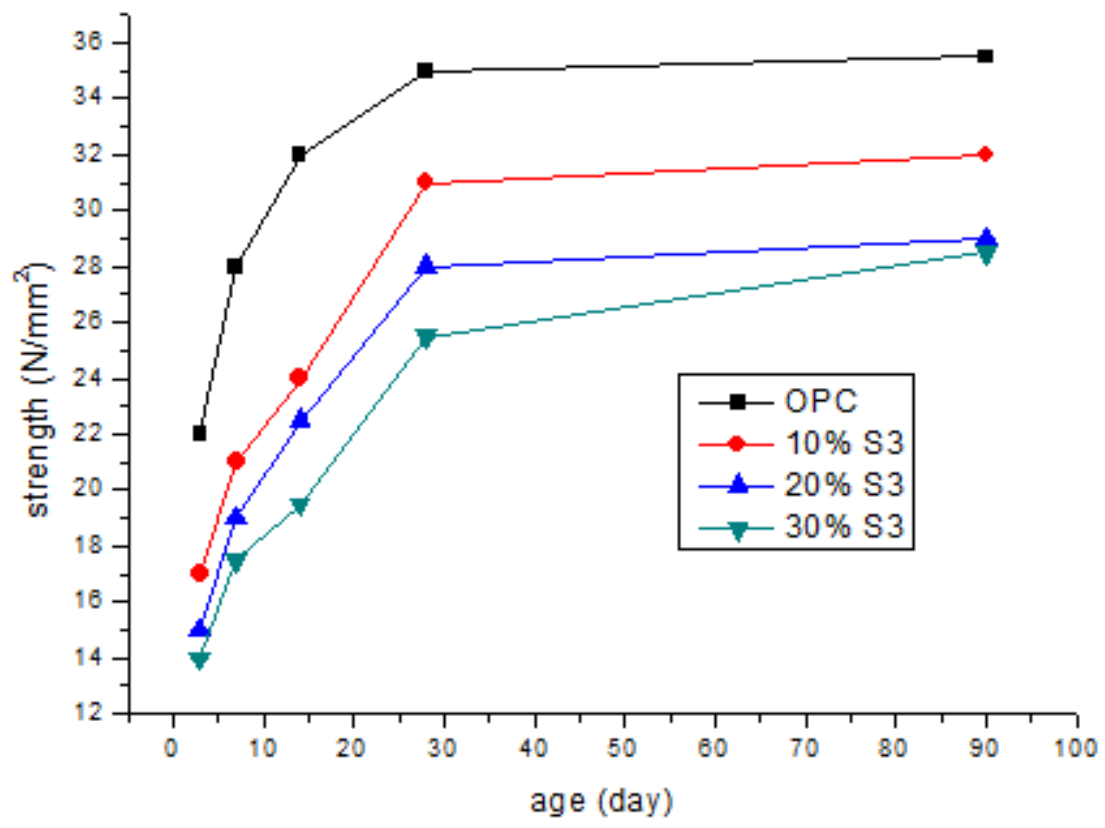

Figure (6) Strength development throughout the ages of S3 Sample replacement proportions compared with OPC.

$$
\begin{aligned}
& f^{\prime}=27.418+0.1085 \mathrm{~d} \\
& \text { (1). For OPC }\left(\mathrm{R}^{2}=0.303\right) \\
& f^{\prime}=20.928+0.143 \mathrm{~d} \\
& \text { (2). For } 10 \% \mathrm{~S} 3\left(\mathrm{R}^{2}=0.510\right) \\
& f^{\prime}=19.008+0.13 \mathrm{~d} \\
& \text { (3). For } 20 \% \mathrm{~S} 3\left(\mathrm{R}^{2}=0.434\right) \\
& f^{\prime}=16.914+0.144 d \\
& \text { (4). For } 30 \% \mathrm{~S} 3\left(\mathrm{R}^{2}=0.673\right)
\end{aligned}
$$

Where: $f^{\prime}$ is the strength in $\mathrm{N} / \mathrm{mm}^{2}$ and $\mathrm{d}$ is the age in days

\section{SUMMARY}

Results can be summarized as below:

1. Pozzolanic samples (S1, S2, \& S3) obtained from Bayoda desert produced a reactive material with high contents of amorphous silica and calcium oxide that fulfilled the principal requirements of a Pozzolanic material. A little amount of crystallization of silica present in S1, may have affected the degree of reactivity.

2. The Pozzolanic samples of Bayoda desert affect the workability of the fresh concrete clearly, particularly the sample $\mathrm{S} 2$.

3. Mechanical strength tests confirmed the actual behavior of the Bayoda pozzolana blended cement substitution of OPC with the samples, gave better strength development results in comparison with OPC specimen.

\section{REFERENCES}

[1] "Pozzolanas- An Introduction", Low-Cost Cement- Intermediate Technology Group Ltd, 1994.

[2] "Pozzolanas- ITDG Publications", Low-Cost Cement- Intermediate Technology Group Ltd, 1992.

[3] Mamoun Eltayeb Elmamoun. "Natural pozzolana in Sudan” Ph.D thesis, University of Khartoum 2004.

[4] Neville A.M. "Properties of Concrete". Third Edition. Apitman International Text, 1981.

[5] Cabrera J.G., Jalali S. and Castro Gomes J.P., "Characterization of Cement Microstructure and Concrete Durability Using Fractal Geometry", 12th European Ready Mix Concrete Conference, ERMCO98,Lisbon. Portugal, 1998.

[6] Cabrera J.G., Jalali S. and Castro Gomes J.P., "Fractal Geometry Used for Characterization of Cement Microstructure and Concrete Durability, European Ready Mixed Concrete", 1998.

[7] ASTM 6118 - 78. "Chemical specification of Pozzolana".

[8] ASTM C - 593-95. "Specifications for Lime - Pozzolana Cement". 
[9] Castro Gomes J.P., Cabrera J.G. and Jalali S., "Modeling the Degree of Cement Hydration Using Electron Backscattered Imaging", Diamond Symposium, Hawaii, USA, (Submetido), 1998.

[10] Eljah Agivi, Otto Rusdulis, "Lime and Alternative Binder in East Africa", IT Publications 1995.

[11] "Pozzolanas- Lime- Pozzolana Cements", Low-Cost Cement- Intermediate Technology Group Ltd, 1994.

[12] "Pozzolanas- Portland- Pozzolana Blended Cements", Low-Cost Cement- Intermediate Technology Group Ltd, 1994.

[13] Sulieman, S. H. Sulieman M. and Elfiel, A. "Gudie uses of Pozzolana in Sudan". Workshop on industry of building in Sudan U. of K Khartoum, Sudan. (In Arabic). 1999.

[14] Elsharif M. Ibrahiem, Salih A. M. Ahmed "Evaluation of Jebel Marra Volcanic Ash as Supplementary Cementitious Material for Use in Blended Cements".IOSR Journal of Engineering (IOSRJEN). Vol. 04, Issue 03, pp. (31 - 37) (March. 2014).

[15] Cusens A. R. and Cabrera J.G. "Developments in Concrete and Related Materials". Paper presented at New Materials and their Applications, Warwick,1987. 